\title{
Evaluate the Use of Moodle Platforms for Education in University of Duhok Using Online Survey Application
}

\author{
Jihan A. Rasool and Sarhan S. Dawood
}

\begin{abstract}
Development countries uses E-Learning as a form of education to cooperate with the challenges of globalization, the birth of the internet and so on. Moodle is a Learning Management System (LMS) which is a free open source platform designed to assist educators in creating online courses with opportunities for dynamic interaction. In this paper the meaning of Moodle was carried out, then the web form (Google Form) is created as a Database to store the answers, gathering feedback and as statistical software to provide analytics of the effect of using Moodle by the lecturer's opinion or perspective in College of Engineering, University of Duhok (UoD), Kurdistan Region of Iraq; their questioners are completed on the internet. The study results point out that $72.55 \%$ of lecturers were interested in services provided by Moodle@uod, mostly utilized as a depot for getting the course's materials but the interactive learning tools are not effectively invested. Where $29.73 \%$ used the application in making quizzes; $32.43 \%$ for communicating with their students this is because of the instability of internet services. For that, the authors suggest satisfying academic staff desires in taking training courses to be more familiar with using Moodle Platform.
\end{abstract}

Index Terms-Learning management system, moodle, Google form, e-learning.

\section{INTRODUCTION}

Nowadays there is a transformation from the traditional learning to the online learning, because the appearance of internet, social media, globalization, and World Wide Web, all these things lead to have glut of data which need a special Techniques to deal with it, thus leads to the need of using ELearning (EL).

The researchers studied the benefits of using EL; where the learner does not need the teacher to be in the same physical location, which will supplement and support the traditional face-to-face learning [1], [2].

Clark and Mayer defined the EL term, as: "instruction delivered on a digital device such as a computer or mobile device that is intended to support learning" [3] (p. 8).

Anderson [4] believed that EL, distance learning, Internet learning, virtual learning, and others online terminologies, are describing learning that is being practiced online. The authors argue that independent of which terms being used, they have commonalities such as:

Manuscript received December 10, 2019; revised July 20, 2020

The authors are with Computer Science Department, Duhok University, Dahuk, Iraq (e-mail: drjihanrasool@uod.ac, sarhan.dawood@uod.ac).
1) All of them use some form of technology (usually a computer) to access the learning materials.

2) The learner and tutor are at different distance from each other. And uses the technology to interact with each other [4].

Europe and North America faced a change in higher education through the use of EL which leads to the development of their country. The Nordic countries are regarded as world leaders of EL as using all aspect of technology in education. However, many developing countries are in preliminary stage of using EL because they suffered from various aspects such as lack of information of how to access the tools of EL, poor infrastructure and technological skill, weak support from their universities and institutions [2], [5].

A learning management system (LMS) is a software application for administration, documentation, Reports preparation, and Hold training and educational courses, or learning and development programs. The concept of LMS spouted directly from e-Learning. For that LMS is the core of the any EL system, whether it is commercial or open source LMS platform [6]-[9].

There are many reasons of adding and integrating LMS with education in universities, as it valuable their infrastructure, increase flexibility, accessibility, scalability, solve the problems of physical space limitation by using virtual content, reduces the costs of courses, improve their ranking to cooperate with global and technology development, and to competitive with other universities around the world [10]-[16]. For universities students LMS encourage them to cooperate with instructors to easily access the courses and cooperate with the virtual educational network as the young people now are more interested with the social media and internet and as seen in the paper referenced [14]. UoD student's also affected with the social media as there are an association relation between the social media and education in UoD, so the LMS will increase the UoD student's knowledge.

The primary mission of educational institutions including UoD, the creation, protection, integration, transmission and applying of knowledge, so Incorporation of knowledge management $(\mathrm{KM})$ into EL provides group/team learning which helps to improve the creation of new knowledge and improve the performance of learning [17]-[19].

One can see that the mission of educational institutions is synchronized with the functionalities of KM. Thus it is logical that KM tools and technologies can be applied to EL through a portal for EL system, where course coordinator can post schedules, assignments, posting comments, 
announcements, news, quizzes, and other LMS activities on the portal [19].

Many papers and researches study the Moodle platform, the study of using functionalities of Moodle and their tools at the University of Aveiro (UA), Portugal was analyzed depending on interview with their students and indicated that the Moodle in UA was mainly depend on using it for repository of material [10].

In German Jordanian University (GJU), Amman, Jordan, the evaluation of the Moodle depending on 46 student's feedback was studied and indicated the interactive tools of Moodle were not actively utilized, only the access of materials were used and imposes the expanded of using these tools for interactive learning environment [11].

The navigation structure of Moodle in two universities of Pakistan was evaluated and focuses on many guidelines that must be improved [12].

The assignment, feedback, quiz and workshop modules among other several features of Moodle were considered very essential and were heavily used at Kajaani University, Indonesia depending on their student's feedback [13].

These studies and researchers force of using Moodle platform in higher education and also must force the universities to changing their way of teaching strategies toward of using EL in education they used interview for gathering their data.

To cooperate with development universities in the development countries in the World, and as seen in the research done by reference [14] that the students in UoD were affected by the Social Media and there was a relation between the social media and education in this university.

As the UoD decided to use Moodle platform in the educational process in the academic departments of the university, and work to create the necessary infrastructure, Evaluation of using Moodle in UoD was carried out through online questionnaire feedback from a sample of academic staff.

Google Form was created as a DataBase (DB) to store the answers obtained from this questionnaire to perform statistical analysis of the survey results.

The structure of this paper is organized as the following sections; in the first section of the paper, main topics are presented. In second section the description of Moodle platform and their design in UoD was discussed. Section three describe the online survey application especially Google Form and its beneficiates. Section four discusses the usage of Moodle platform and their tools which help teachers in their way of teaching the students, the study carried out in the college of engineer, UoD, Kurdistan region/Iraq. This section contributes the Google Form for analyzing and evaluating of using Moodle in UoD and their results were point out.

\section{MOODLE AS LMS PLATFORM}

Moodle (corresponding to Modular Object-Oriented Dynamic Learning Environment) is a free and open source EL platform designed to provide educators, administrators and learners with a single robust, secure and integrated system to create personalized learning environments, based on socio constructivist point of view proposed by Dougiamas in 1999, allows users to incorporate different resources and functionalities in a modular structure [15]-[17]. Moreover, Moodle can be considered as a Course Management System (CMS), used to manage and evaluate the students' trajectory , monitor their performance, create and distribute courses content, arrange e-activities, along with to, provide tools for communication, interaction with others in the team work whom involve in the learning process [16], [17], [20].

Moodle provide the users by some flexible tools which can be mainly utilized remotely to access course materials, including lecture slides, assignments, quizzes, and news, these course materials are mostly prepared using some software tools, such as Microsoft Office, which can be uploaded to the EL system. Moodle also provide users with some interactive learning tools which can be prepared using the module functionalities of Moodle, including feedbacks, discussion forums, workshop, chats, wikis, questionnaires, and surveys, as well as managing their tasks with their timetable, besides offering a wide variety of complementary tools to support the teaching and learning process [10], [17].

Course material with other data used by the learning system in Moodle platform will be stored in mor than 200 databases which will be under the control of a LMS. These Databases as one of activities provided to users, is usually Microsoft SQL Server or Oracle but can also be MySQL or Postgres.

The database activity module allows the students and/or teachers to create, search and display a bank of set of entries about any possible topic. The format of these entries can be almost unrestricted, including images, videos, URLs, numbers and texts amongst other things.

The structure of database in Moodle environment is defined in "install.xml" files inside a folder named "DB" in each plugin. For example, the database for forum Module can be called as "mod/forum/db/install.xml", and tables used in the core of Moodle, can be called as: "lib/db/install.xml" [16], [20]-[22].

There are three advantages of using Moodle and make it special in the CMS: educational philosophy, open source and community [15], [16].

According the classification presented by [23] the Moodle platform is grouped in two classes:

(1) Resources: digital instructional materials that are usually uploaded to the platform, such as files, Web pages, PowerPoint, flash animations, word documents, video and audio files.

(2) Modules: are components used for the cooperation between the teachers and students and are created by Moodle platform itself such as Database, Assignments, Forums, Workshops, Chats, Glossary, News, and Wikis. The activities and modules of Moodle Platform includes [24]-[27]:

(1) Creating a database.

(2) Organizing a lesson, represent a set of ordered topics summarizing the instructional materials and allow the access to them through the respective link

(3) Delivering an assignment, allow teachers to collect and evaluate the uploaded assignment files from students and provide feedback including grades

(4) Deliver a workshop to the users Participating the system

(5) Provide communication activities by allowing synchronous conversation (chat), exchanging ideas 
between students and teachers through posting comments (forums), allow teachers to add posts, announcements, and to send emails (news).

(6) Provide Collaboration activities, by allowing teachers creating and maintaining Glossaries and allow users to edit collaborative Web pages (Wikis).

(7) Provide Assessment activities, by allowing teachers to build quizzes and ask different types of questions, and permits them to create surveys and get feedback from students.

(8) Reusability activity, enabling Shareable Content Object Reference Model (SCORM) packages, as a collection of standards and specifications for EL technology to be included in the course, and provide access to new EL resources tools or materials on other Web sites (external tools).

\section{GOOGLE FORM}

Google Form is a free service from Google; it is a web form or web-based application that is created as a Database to store the answers, gathering feedback and as statistical software to provide analytics of the survey; their questioners are completed on the internet. The gathered data using the form is typically stored in a spreadsheet.

Google form can be used to make a survey to collect answer online by sending a link message, email or embedding it into blog post on their page.

There are many online survey apps on the internet, but Google Forms is an excellent free option between students and teacher to share questions and answers or make a survey. [27], [28]

Google Forms supports various types of questions such as: text, which is used for short text answer questions. A paragraph type is for longer text answer (or essay) questions. Multiple choices are for questions in which respondents are allowed to choose only one item as their answer. Choose from a list, checkboxes, scale, and grid, allows respondents to choose more than one item.

By using one or more of these ways of questions, the instructors can make a set of questions which are then shared on webpages. Students access these webpages using their computer workstations in a lab classroom. This process is similar to that of filling out on-line questionnaires [29].

The advantages of using Google Form are:

(1) Meet Curriculum Objectives by creating survey.

(2) Multiple Ways to Administer Forms

(3) By using beautiful themes we can create professional looking forms

(4) Using different types of Questions.

(5) Apply Validation Options to Control Data Entry

\section{EXPERIMENTS AND RESULTS}

College of Engineering at UoD, worked on investigates different aspects of using EL, especially Moodle platform from academic staff opinion and perspective. The academic staffs were asked online to fill questionnaire forms by sending the link of Google Form; their answers were analyzed using Google Form also.
The aim of the questionnaire questions is to show how EL will facilitate the lectures preparation for use and study the facts influencing lecturers in using Moodle in their way of teaching and to explore their opinion by using Moodle.

The questionnaire included asking 10 questions to a sample of 60 academics with different qualifications (B.SC., M.SC, and PHD).

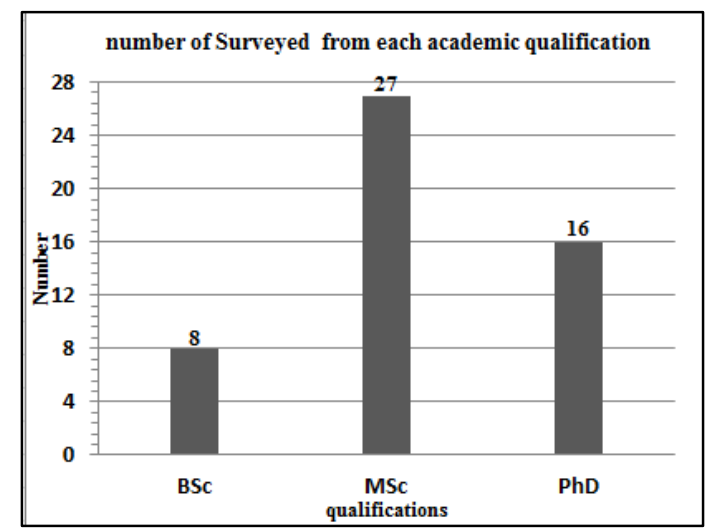

Fig. 1. The corresponding percentages according to the qualifications.

Fig. 1 shows the number of academics whose views were taken in the questionnaire according to their academic qualifications.

These questions require answering by Yes or No in order to clarify their views on applying LMS based on Moodle platform at UoD Colleges. After retrieving the questionnaire forms, 9 forms were neglected due to their inaccuracy.

Table I summaries the answers (Yes/No) of each question.

Depending on Google Form the analysis of the Results of survey can be summarized in terms of answers on each question as follow:

1) For the question number 1: Have you used learning Management System before?

Google Form analysis of the answers of this question show that more than $72.55 \%$ of Surveyed answered by YES, which means that the UoD's academics are knowledgeable of LMS's and understand the importance of developing such type of systems.

This indicates a clear growth in the culture of the digital world and the Internet among academics at the UoD, and it is confirmation of the results from a previous study conducted on UoD students in Kurdistan region of Iraq on the importance of social media in managing digital education and understanding its benefits [14].

2) For the question number 2: Have you used UoD Moodle?

The analysis for the answers of this question indicated that $72.55 \%$ answered by YES, which shows that the teaching staff at UoD are interested and trusted the benefits of using Moodle in teaching and communicating with their students remotely.

3) For the Questions from 3, up to 9 which related to the main activities and tools provided by Moodle, The answers that we got about these questions from those who were surveyed and confirmed their use of this system (30 persons), indicated the following:

- $81.08 \%$ of them declare that Moodle platform is useful for learning/teaching process

- $\quad 67.57 \%$ feel confident to use Moodle in their lectures.

- $29.73 \%$ expressed that they use Moodle for making 
quizzes.

- $\quad 32.43 \%$ expressed that they use Moodle's messaging system for Communicating with their students.

- $\quad 45.95 \%$ find that the Moodle Platform is an enjoyable and effective way for their students during teaching process.

- $\quad 72.97 \%$ feel that the Moodle has a friendly user interface.

- $\quad 32.43 \%$ find that using Moodle in their teaching system valuable way of affecting positively on students teaching.

although the academic staff confirmed with a high rate (81.08\%) that the Moodle platform achieves benefits for the education system at the university, but analyzing the percentages indicated above, we find that there is a shortage from some of them in taking advantages of some activities offered by this system, which requires holding seminars and workshops in order to encourage them to use these powerful tools, through introducing them to the benefits of investing these service activities provided by the system, and providing recommendations to Presidency of the university in order to improve internet services because it was among the reasons that some academic staff refrain from using these facilities, such as quizzes and communicating remotely with their students.

4) For the question number 10: I need to undergo more training to be familiar more with the Moodle Platform.

Google Form analysis of the answers of this question show that $82.35 \%$ from those who were surveyed, need more training courses to be more familiar with the Moodle Platform, This high percentage confirms the desire of the teaching staff to use this system in their teaching tasks by announcing their desire to enroll in training courses that contribute to developing their skills in how to use this system and benefit from it

TABLE I: SUMMARY OF THE QUESTIONNAIRE RESULTS ACCORDING TO THE ANSWER OF EACH QUESTION

\begin{tabular}{|c|c|c|}
\hline Questions & No. of YES & No. of NO \\
\hline $\begin{array}{l}\text { Have you used any Learning Management System before? } \\
\text { With their percentage }\end{array}$ & $\begin{array}{c}40 \\
(78.43 \%)\end{array}$ & $\begin{array}{c}11 \\
(21.57 \%)\end{array}$ \\
\hline $\begin{array}{l}\text { Have you used UoD Moodle? } \\
\text { With their percentage. }\end{array}$ & $\begin{array}{c}37 \\
(72.55 \%)\end{array}$ & $\begin{array}{c}14 \\
(27.45 \%)\end{array}$ \\
\hline $\begin{array}{l}\text { Do you find Moodle platform useful for learning/teaching process? } \\
\text { With their percentage. }\end{array}$ & $\begin{array}{c}30 \\
(81.08 \%)\end{array}$ & $\begin{array}{c}7 \\
(18.92 \%)\end{array}$ \\
\hline $\begin{array}{l}\text { Do you feel confident to use Moodle in your lectures? } \\
\text { With their percentage. }\end{array}$ & $\begin{array}{c}25 \\
(67.57 \%)\end{array}$ & $\begin{array}{c}12 \\
(32.43 \%)\end{array}$ \\
\hline $\begin{array}{l}\text { Do you use Moodle for making quizzes? } \\
\text { With their percentage. }\end{array}$ & $\begin{array}{c}11 \\
(29.73 \%)\end{array}$ & $\begin{array}{c}26 \\
(70.27 \%)\end{array}$ \\
\hline $\begin{array}{l}\text { Do you use Moodle for Communicating with your students - by using Moodle's messaging } \\
\text { system? With their percentage. }\end{array}$ & $\begin{array}{c}12 \\
(32.43 \%)\end{array}$ & $\begin{array}{c}25 \\
(67.57)\end{array}$ \\
\hline $\begin{array}{l}\text { Is Moodle Platform an interested way for your students when you teach them? With their } \\
\text { percentage. }\end{array}$ & $\begin{array}{c}17 \\
(45.95 \%)\end{array}$ & $\begin{array}{c}20 \\
(54.05 \%)\end{array}$ \\
\hline $\begin{array}{l}\text { Do you feel that the Moodle interface is user friendly? } \\
\text { With their percentage. }\end{array}$ & $\begin{array}{c}27 \\
(72.97 \%)\end{array}$ & $\begin{array}{c}10 \\
(27.03 \%)\end{array}$ \\
\hline $\begin{array}{l}\text { Do you find that using Moodle with your teaching system valuable way of effecting your } \\
\text { students' education? With their percentage. }\end{array}$ & $\begin{array}{c}12 \\
(32.43 \%)\end{array}$ & $\begin{array}{c}25 \\
(67.57 \%)\end{array}$ \\
\hline $\begin{array}{l}\text { I need to undergo more training to be familiar more with the Moodle Platform. With their } \\
\text { percentage. }\end{array}$ & $\begin{array}{c}42 \\
(82.35 \%)\end{array}$ & $\begin{array}{c}9 \\
(17.65 \%)\end{array}$ \\
\hline
\end{tabular}

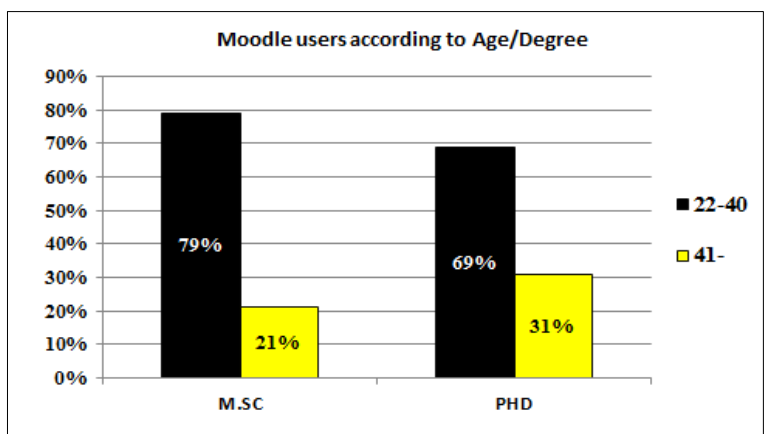

Fig. 2. Moodle users according to age/degree.

One of the important results gotten from study as seen from Fig. 2 is that, the young category of academic staff, Of those between 22 and 40 years old, were interested in using Moodel platform with $69 \%$ for $\mathrm{PhD}$ holders and $79 \%$ for master's, while for older ones (greater than 40 years) were $31 \%$ for $\mathrm{PhD}$ holders and $21 \%$ for master's. From these results, we can conclude that the academics who Contemporaries the period of the Internet and social media are more willing to accept new technology, including a Moodel platform for communicating and interacting with their students and investing the activities and facilities provided by this application in the field of EL.

\section{DISCUSSION}

The results presented in Fig. 1 demonstrate that 16 of Surveyed academic staff are PHD degree holder, 27 hold a master's degree, and 8 with B.sc degree. This means that The College of Engineering needs to encourage the academic staff to obtain higher degrees in order to keep pace with the development in the field of information technology and its applications.

The data presented in Table I demonstrate that $72.55 \%$ from whom Surveyed uses Moodle in teaching process, and $81.08 \%$ from this percentage find Moodle platform useful for learning/teaching process. However, the interactive learning tools of Moodle are not effectively utilized, where only $29.73 \%$ of them use Moodle for making quizzes, $32.43 \%$ uses Moodle for Communicating with their students by using Moodle's messaging system. This indicates that the interactive learning tools of Moodle, including chats, wikis, feedbacks, forums, questionnaires, and surveys, are underutilized.

The study results point out that Moodle is mostly used as a depot for get course materials, but its interactive learning tools are not effectively invested. Because of that, table I showed that $67.57 \%$ from whom Surveyed find that using 
Moodle with their teaching system is not valuable method in affecting students education, this means that the academic staff need to convince them of the usefulness of this system by introducing them to the experiences of other universities that have succeeded in developing their online education systems.

\section{CONCLUSION}

In this paper, a questionnaire-based study is conducted to evaluate the use of EL system based on Moodle platform of the UoD, collage of engineering, Kurdistan region of Iraq.

The web-based application Google Form was invested to create a Database used to store the collected answers, and utilize the statistical analysis abilities of the application.

The study Surveyed 60 academic staff, only 51 forms from the questionnaire were accepted, because 9 forms were neglected due to their inaccuracy.

The replies of the Surveyed indicate that most of them find Moodle platform useful for learning/teaching process. However, the interactive learning tools of Moodle are not effectively utilized. Most of Surveyed demonstrated a positive perspective towards expanding the use of EL tools in educational process through expressing their desire to taking training courses to be more familiar with the Moodle Platform and activities provided by this system.

The results of our study recommended the Presidency of the university to improve internet services and holding seminars and workshops in order to encourage academic staff to use interactive learning tools of Moodle in the educational process to achieve an effective and interactive learning environment. Moreover, the future mission and plans of UoD must be based on the creation, preservation, integration, transmission and application of knowledge this can be achieved that through Incorporation of LMS activities with $\mathrm{KM}$ processes to improve the creation of new knowledge and improve the performance of group/team learning which helps the improvement of learning activities between learning Parties.

Our future work will focus on a survey of student view on the effectiveness of this platform in improving the educational system and the possibility of shifting towards EL.

\section{CONFLICT OF INTEREST}

The authors declare no conflict of interest.

\section{AUTHOR CONTRIBUTIONS}

J.A.A. conceived the presented idea and contributed the theoretical formalism; J.A.A. and S.S.D. conducted the research; S.S.D. contributed to sample preparation, design the questionnaire and performed the statistical analysis; J.A.A. took the lead in writing the manuscript; J.A.A. and S.S.D. contributed to the interpretation of the results; J.A.A. and S.S.D. wrote the paper; all authors had approved the final version.

\section{REFERENCES}

[1] S. R. Hitz and M. Turoff, "Education goes digital: The evolution of online learning and the revolution in higher education," Communications of the ACM, vol. 48, no. 10, pp. 59-64, 2005.
[2] A. Sife, E. Lwoga, and C. Sanga, "New technologies for teaching and learning: Challenges for higher learning institutions in developing countries," International Journal of Education and Development Using ICT, vol. 3, no. 2, pp. 57-67, June 2007.

[3] R. C. Clark and R. E. Mayer, E-Learning and the Science of Instruction: Proven Guidelines for Consumers and Designers of Multimedia Learning, 3rd ed. Santa Ana, CA, USA: Pfeiffer, 2011.

[4] T. Anderson, The Theory and Practice of Online Learning, 2nd ed. Athabasca, Canada: Athabasca University Press, 2008.

[5] A. Andersson, "Learning to learn in e-learning: Constructive practices for development," Ph.D. Dissertation, Department of Informatics, Örebro University, Örebro, Sweden, 2010.

[6] A. Andersson and $\AA$. Grönlund, "A conceptual framework for elearning in developing countries: A critical review of research challenges," The Electronic Journal on Information Systems in Developing Countries, vol. 38, no. 8, pp. 1-16, July 2009.

[7] Why you must free up navigation in e-learning. [Online]. Available: http://info.shiftelearning.com/blog/bid/241958/3-Reasons-Why-YouMust-Free-Up Navigation-In-eLearning

[8] A. Shahzad, W. Hafizi, and A. G. Golamdin, "E-learning navigation model based on students learning behavior: Case study in UUM," Int. J. Bus. Soc. Sci., vol. 5, no. 5, pp. 118-130, 2014.

[9] S. Graf and B. List, "An evaluation of open source e-learning platforms stressing adaptation issues," in Proc. the 5th IEEE International Conference on Advanced Learning Technologies (ICALT'05), IEEE Press, 2005, pp. 163-165.

[10] C. Costaa, H. Alvelosa, and L. Teixeira, "The use of Moodle e-learning platform: a study in a Portuguese University," Proceedia Technology, vol. 5, pp. 334-343, 2012.

[11] R. E. Bahsh and M. I. Daoud, "Evaluating the use of moodle to achieve effective and interactive learning: A case study at the German Jordanian University," in Proc. the 2nd International Conference on Open Source Software Computing (OSSCOM 2016), Beirut, Lebanon, 2016.

[12] R. Arshad, A. Majeed, H. Afzal, M. Muzammal, and A. Rahman, "Evaluation of navigational aspects of moodle," International Journal of Advanced Computer Science and Applications, vol. 7, no. 3, 2016.

[13] K. C. Deepak, "Evaluation of moodle features at Kajaani University of Applied Sciences - case study," Procedia Computer Science, vol. 116, pp. 121-128, 2017.

[14] J. A. Rasool, "Analysis the relationship between social media and education system in Kurdistan region of Iraq using Chi-Square test," Academic Journal of Nawroz University, vol. 7, no. 4, pp. 133-138, 2018

[15] T. Nagy, "Using learning management systems in business and economics studies in Hungarian higher education," Education and Information Technologies, vol. 21, no. 4, pp. 897-917, 2016.

[16] M. Ivanović, Z. Putnik, Ž. Komlenov, T. Welzer, M. Hölbl, and T. Schweighofer, "Usability and privacy aspects of moodle: Students' and teachers' perspective," Informatica, vol. 37, no. 3, pp. 221-230, 2013.

[17] S. B. Dias, J. A. Diniz, and L. J. Hadjileontiadis, Towards an Intelligent Learning Management System under Blended Learning: Trends, Profiles and Modeling Perspectives, Switzerland: Springer International Publishing, 2014.

[18] J. Pattnayak, S. Pattnaik, and P. Dash, "Knowledge management in elearning a critical analysis," International Journal of Engineering and Computer Science, vol. 6, issue 5, pp. 21528-21533, May 2017.

[19] G. Sammour, J. Schreurs, A. Y. Al-Zoubi, and K. Vanhoof, "The role of knowledge management and e-learning in professional development," Int. J. Knowledge and Learning, vol. 4, no. 5, pp. 465477, 2008.

[20] W. Rice, "Moodle: E-learning course development - a complete guide to successful learning using moodle," Birmingham, United Kingdom: Packt Publishing, 2006.

[21] Y. Kats, Learning Management System Technologies and Software Solutions for Online Teaching: Tools and Applications, Hershey, Pennsylvania, USA: IGI Publishing, 2010.

[22] K. Harężlak and A. Werner, "Database access and management with the use of the moodle platform," in Human-Computer Systems Interaction: Backgrounds and Applications, Advances in Intelligent and Soft Computing, Z. S. Hippe, J. L. Kulikowski, and T. Mroczek, Eds. Berlin, Heidelberg: Springer, vol. 98, part I, pp. 49-65, 2012.

[23] J. Cole and H. Foster, Using Moodle, Teaching with the Popular Open Source Course Management System, 2nd ed. Newton, MA, USA: O’Reilly Media, Inc., 2008.

[24] F. Blin and M. Munro, "Why hasn't technology disrupted academics' teaching practices," Computers \& Education, vol. 50, no. 2, pp. 475490, 2008.

[25] K. Harezlak and A. Werner, "E-learning database course with usage of interactive database querying," In Internet-Technical Development 
and Applications. Advances in Intelligent and Soft Computing, E. Tkacz and A. Kapczynski, Eds., Berlin, Heidelberg: Springer, vol. 64, pp. $81-89,2010$

[26] A. Daneshmandnia, "A usability study of moodle," in Proc. the Spring 2013 Mid-Atlantic Section Conference of the American Society of Engineering Education, 2013, pp. 60-84.

[27] C. Love. (Dec. 2014). 5 Reasons to Use Google Forms with Your Students. [Online]. Available: https://www.technokids.com/blog/apps/reasons-to-use-google-formswith-your-students/

[28] T. Kato, Y. Kambayashi, and Y. Kodama, "Practice for self-regulatory learning using google forms: Report and perspectives," Information Engineering Express International Institute of Applied Informatics, vol 2, no. 4, pp. 11-20, 2016.

[29] A. Z. Mansor, "Managing students' grades and attendance records using Google forms and Google spreadsheets," Procedia - Social and Behavioral Sciences, vol. 59, pp. 420-428, 2012.

Copyright $(92020$ by the authors. This is an open access article distributed under the Creative Commons Attribution License which permits unrestricted use, distribution, and reproduction in any medium, provided the original work is properly cited (CC BY 4.0).

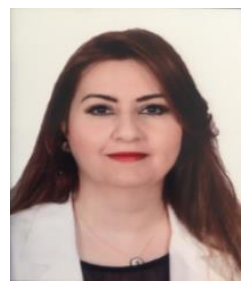

Jihan Abdulazeez Rasool is a professor of computer science in Duhok University/Iraq. She has $\mathrm{PhD}$ in computer science (database and data mining), M.Sc. degree in (IT) information technology and computer science (communication and artificial intelligence), and B.Sc. degree in computer science. Her research interests lie in the areas of knowledge management systems, database /data mining, elearning, and holonic manufacturing system. She has a strong background in the field of database, data mining, object relational database, data warehouse, e-learning, and swarm intelligence. She works in many fields of computer science in many Universities of Iraq. She works as a consultant IT and program assistant at the Ministry of Higher Education \& Research in Baghdad, Iraq in 2003 till 2004, and as a software developer and reporting statistic officer at UN-Habitat/Duhok Field Office. She was responsible for creating and construction a database for retirement pension, UN-Habitat organization, Duhok, Iraq, Jul. 2001 till Jun. 2002. Also she works as a program assistant and software training teacher at Higher Institute for Computer Science, Baghdad, Iraq, 2001. She has twenty years' work experiences in the field of computer science, database and data modeling, information technologies, and operating system. She participated as a session chair, and presentation in oral and technical presentation, recognition and appreciation of research contribution to ICAINN 2015: $17^{\text {th }}$ International Conference on Artificial Intelligence and Neural Network, WASET Conference, Paris, France, 2015. She published many papers and participation in many conferences in Iraq and also, she was the chair of many scientific workshops in Iraq. She worked as supervisor for more than fifteen projects of database and e-learning in University of Duhok like (hospital management system, elibrary, building data warehouse for stock system, online shopping, online restaurant, and many other data management in different fields).

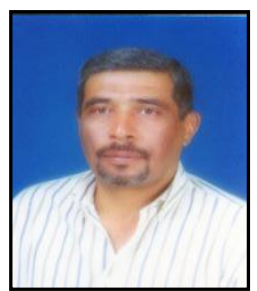

Sarhan S. Dawood is a lecturer in the Department of Computer Science, College of Science, University of Duhok, Iraq since 2009. $\mathrm{He}$ received the master degree in applied computer science from Institute of Advanced studies in computer science \& information in Baghdad/Iraq, in 1987. He worked as a staff member at Al-Mustansiriyah, Iraq for the period between 1988 and 1999, and Al-Balqa' Applied University, Jordan for the period between 1999 and 2009 during which he held many positions, including director of the Computer Center and head of the Department of Basic Sciences .His research interests include information system technology, database, computer network technology, and e-environment. 